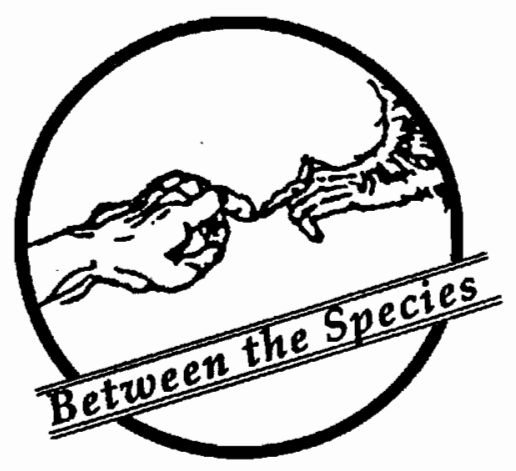

\title{
ST. MARTIN'S SUMMER
}

\author{
Jon Wynne-Tyson \\ Fontwell, West Sussex
}

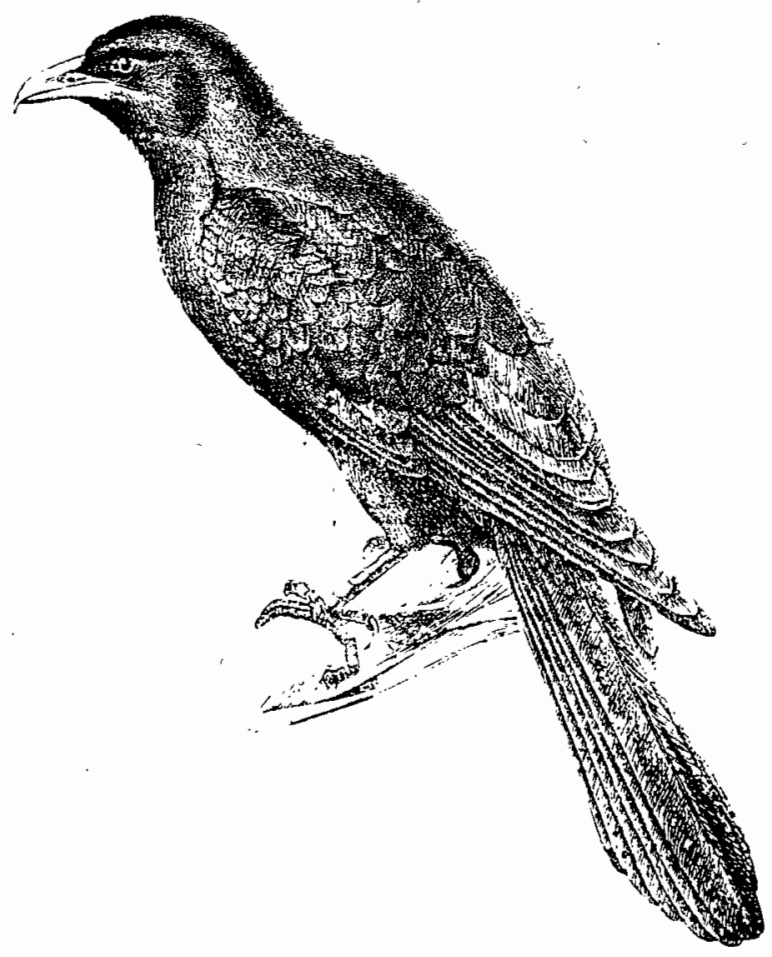

$\left.\prod\right]$

e pushed the deck chair deep into the tangle of briar and dried bracken. The 1 rug followed, then the small flat bottle of gin. He would bring the rest the next day, when it was Sylvia's turn to have the car and she would be dropping him for his walk, saving a mile of boring road work.

"Come on, Roddy," he said. "Homies."

So that was it. Ready to go. As he walked back to the car, keeping his balance on the rutted path by stabbing touches of his stick, he went through the details once again. Meticulous, he knew he had made no mistakes, forgotten nothing. But this was the big one, as Kojak would say; a little extra thought was justified.

Ahead, the labrador snuffled eagerly, erratically, his nostrils tantalized by rabbit, squirrel and the plentiful pheasants that ran, whirred and rattled out of their path. So early in the shooting season the woods were alive with the fat, sleek birds, timid and indignant at such disturbance after many weeks of being pampered and hand-fed by the gamekeepers.

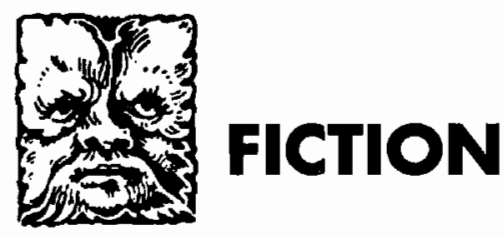


The car was a mile and a half down the lane and across two fields. As was usual on this lonely part of the Downs, they had met no-one. Before his leg had begun to play up, they could walk for five or six hours without seeing a soul. Even at weekends a few hundred yards would shake off all but the most dedicated leisure-users.

He was not sorry to sink into the driving seat. It had been taxing to carry the bits and pieces up the hill over cattle-churned fields and the rough-surfaced bridleway. On the dull cold day the Agawarmed kitchen was a welcome prospect.

Sylvia had bought a packet of crumpets. They had two each for tea.

T4 ver since he had planned this day he had 1 wondered whether he would go through with it. Not only whether, but how. Saying good-bye to Sylvia, for instance, for what she could not guess was the last time.

When it came to it, it was much like any other day. It had to be. Only the business of not taking Roddy was out of step.

"He'll be rather disappointed," Sylvia said. "Such lovely weather, too. Almost like September. Yesterday I thought winter had arrived."

"I know. But it's better I go alone. I do want to get up to the folly again while I still can, and there are so many pheasants up there."

"He wouldn't kill any surely?"

"It's the disturbance. I promised Rogerson."

"You must take him with you to-morrow, then. You've never left him behind before."

"Of course."

So she dropped him at the bottom of Puck's Lane, a mile from where he had driven the previous day. That was part of his plan. From Puck's Lane she would not imagine him cutting across country to pick up a route that for years had been quite a different walk. It would postpone discovery enormously.

He said "See you later," and she smiled and drove off just as on any other day when she dropped him. He watched the Mini out of sight, perhaps slightly hot behind the eyes, but strangely calm.
TYnsurprisingly, the things were still there. Few spots on the Downs were more remote. Opposite the plantation of beech, oak and ash of greater age had given most of their leaves to the bridleway's carpet of brown and gold which the strengthening sun would crisp into giant cornflakes before the November day was done. He felt guilt at denying Roddy his walk, missing his company. The dog's joy in dried leaves was like that of a small boy.

The rug seemed quite dry, despite the light rain that had fallen in the night. Wouldn't do to get a chill...

With a faint smile he tucked the rug under one arm, pocketed the gin bottle and picked up the chair. Then he walked a hundred or so yards to the north before taking the almost indiscernible deer track through the plantation. After a few minutes he was in to older woodland, picking his way over fallen branches and whole trees that had lain there for years, of no concern to the foresters. Great beeches, many years beyond their commercial span of life, stood in forgotten splendour, most gaunt with the limb loss of old age, and here and there the dark spread of unimaginably older yews lent a sombre, timeless feel to this neglected corner of the forest.

He reached a moss-covered bank made of flints thrown up centuries before, perhaps as a boundary. Its age was confirmed by the occasional beech tree which topped the bank, erosion exposing massive roots now so barked as to resemble ground-level limbs. He walked up the bank and down into the already sun-warmed hollow on its far side. He had arrived.

The hollow was on the fringe of the forest, facing south over a downward slope of rabbit-cropped turf almost encircled by the forest. Too steep ever to have been disturbed by the plough, in high summer it harboured plants rarely encountered elsewhere on the Downs.

The view was magnificent, taking in some twenty five miles of coastline, beyond which the sea shimmered through the haze drawn by the sun from the drying turf. A rich man with a soul - if that was no contradiction - would have paid a fortune to be allowed to build his house in such a spot.

He had found it years before, when Roddy was a pup. Apart from coming across a snare set on the edge of the woodland, he had seen no sign of 
human life within half a mile. He was confident that on a November weekday he need not fear interruption. He looked at his watch. On schedule.

He set up the deckchair, then covered it with the rug, but it was too warm in the sheltered hollow to bother with wrapping it round himself. For a few minutes he lay back with his eyes closed, enjoying the sun on his face, then shook his head, realizing he might doze off. Every colour was sharper, every shape more clear, for having shut his eyes against the morning sun. A few yards to the west the deeply grooved trunk of an oak was briefly visited by a small grey bird that probed into its recesses. A leafless hawthorn covered in old man's beard, the sun behind it, might have been a cherry tree in blossom.

\section{T $t$ had been the business of using a \\ plastic bag that had put him off}

\section{a bit. There was something}

incongruous, undignified, almost

irreverent, about being found in

such an idyllic spot with a bin liner

over one's head.... But the aesthetic

objection was the strongest. He

smiled, remembering the indignant...

summing up of that environmentally-

sensitive judge: "You have been

found guilty of indulging in unnatural

practices below one of London's

most beautiful bridges."
He removed the flask from his jacket, also another smaller bottle, propping them beside the chair against a fallen branch from the beech above. Then he took out a pen and an envelope, removing two sheets of writing paper. He propped them, half folded, against the back of his open wallet to give enough firmness for writing.

Sylvia, old girl, I'm sorry about this, but it seemed the best way. We feel the same about ending up on some geriatric ward, so I think and hope this won't be too much of a shock for you. I'm afraid it's going to put a few people to some trouble and expense, but not as much as having me lying around in hospital fighting their determination to keep me a well-behaved vegetable. That as you know is the one prospect that has ever really scared me.

The doc's report last week wasn't too good. Could be six months, might drag on for three years. What with that, the leg, the kids making their own way, the timing seems about right. You're young enough to do more with your life than nurse a declining husband. I hope you'll sell up and go and live near Mary. You're happier with that kind of climate than I am. The sun I'm sitting in at this moment is just my cupper.

Explain to the children, won't you? They may think I've chickened out, but they'll understand in time. I don't want them to feel this decision has all that much to do with us not hitting it off as well as we might, because it hasn't. Most marriages are a compromise, and I don't think you and I have made too bad a job of if, all things considered. Think about taking up again with Bob Sullivan. You've known him longer than you've known me, after all. Now his wife's snuffed it you'll be in the same boat. He's probably not a bad chap when you get to know him!

A movement on the fringe of the wood disturbed his concentration. It was a deer grazing the short grass. A veil of gossamer drifted slowly over the turf across the blue sky, like a backdrop, the long filaments shimmering in the sunlight. Some of the silken threads had hung themselves on a yellow- 
leafed field maple a few dozen yards to the east. Behind the maple a tall holly, its branches heavy with red berries, still glistened with held pockets of the night's rain. For a few moments he was mesmerized by the beauty of the scene, then he moved the paper and the deer bounded silently back into the forest, her ears pricked with instant alarm.

It's so lovely up here. A sudden St. Martin's

Summer. I know you don't get quite the same

kick out of the countryside, but I hope you can understand my wanting to peg out while I can still enjoy it. Selfish, I suppose, but there's no point in my being a drain on you and the rates just so that I can grow old ungracefully.

Coming to a halt up here makes sense somehow, though my apologies to whoever has to fish me out. I feel bad about leaving you to cope, but I'd have been the first to go anyway and this is less messy. Anyhow, I'm starting to justify myself, so I'd best pack it in and get down to the practicalities.

His attention was distracted again, this time by a brace of pheasants emerging from behind a low bush on the edge of the turf where the ground was spongy with moss and humus and the grass thin below the trees. The birds were engrossed in each other, the cock attentive, the hen receptive, vocally communicating with low notes like those of doves, but harsher. They circled each other, pecking at the ground and billing, then as though their feelings had got the better of them they retired to the privacy of a hollow in the flat-topped bush and billed and cooed and rubbed up against each other in a way he had never before seen in pheasants.

He could tell by sound more than sight that the birds were too immersed in each other to be alarmed by his slight movements. He wondered at the intensity of their feelings when it was not even the mating season. Pheasants had always seemed so stupid, making such a shindy as they flew in dead straight lines, their brief existence dependent upon the strange passion of some well-fed stockbroker to bring them to hard earth in a bumping flurry of soft feathers. It was easy to forget that even at that level of life there could be dependence and communication, a kind of joy.

He tried to finish his letter, but the ending eluded him. His watch told him an hour had passed.
He had better get on with the day's business. He looked at the gin bottle with disinterest. Neither time nor place seemed right for getting sozzled. His perceptions were sharp, in harmony with his surroundings. But it was the classic method, favoured by most medical men who took their own lives, so as that was why he was there...

He unscrewed the cap and took a mouthful of the contents, glad he had diluted it with tonic water. Now maybe the right conclusion for his letter would come to him.

Suddenly the pheasants squawked and ran from under the bush, their legs going at comic speed before they took off heavily down hill. For a moment he was worried that someone was approaching, for he had made no particularly sharp movement that might have frightened them. Then he saw the reason for their panic.

"What the devil!" he exclaimed. "Roddy!"

The dog, the pheasants' scent forgotten, raced over to him and went through the full reunion routine. He fondled the animal's head fiercely, half in anger, half gladly.

"You rascal!" he said. "You got out. How the hell did you know where I was?"

Roddy sat beside him, panting. He guessed the dog had covered a lot of ground before picking up his scent. Over the years they had taken many of the wide choice of footpaths.

"You old blighter," he said gruffly. He felt the dog's neck. "You haven't even got a collar. You could have got yourself shot. Some keepers only want an excuse."

He breathed deeply, feeling sudden need to muster resolution. His nostrils felt the pungent, long-loved scent of rotting oak leaves, one of the compensations for each dying year, though now a little in competition with the aftermath of gin.

"This won't do," he said. "You've got to go home."

He imagined his body and that of the dog being found together days, even weeks, later, then told himself to stop sentimentalizing. Hunger would drive the animal home. He lay back in the chair, his hand resting on the dog's back, trying to focus his mind on essentials. A thing worth doing was worth doing well. The adage had governed so much of his life.

He picked up the smaller bottle, giving it a quick, pointless shake. All present and correct. 
Fifteen $100 \mathrm{mg}$. capsules of pentobarbitone plus five for good measure ...

Christ! He'd forgotten to take the travel-sickness pill. Charles had advised one an hour before the capsules. "Less chance of bringing them up." Right, no more mucking ...

He swallowed the pill without taking more gin, in case the combination put him into only temporary sleep. Bloody hell, was he so feeble-minded he couldn't even remember the precaution he had known about from the day he sought his brother's advice? Good old Charles! None of that rubbish about the Hippocratic oath. Blood was thicker when it came to the crunch. "A small breakfast, Toby. Something bland. Porridge would be fine. Calms the stomach without delaying absorption. And dilute the gin; it'll reduce the chance of nausea ..."

It had been the business of using a plastic bag that had put him off a bit. There was something incongruous, undignified, almost irreverent, about being found in such an idyllic spot with a bin liner over one's head. All right, combined with the sedatives it made the result more certain, but somehow it seemed to be trying too hard. Rather like setting the spinnaker in a steady breeze with only half a mile to go to the finishing line, and the next boat four hundred yards behind. But the aesthetic objection was the strongest. He smiled, remembering the indignant if possibly apocryphal summing up of that environmentally-sensitive judge: "You have been found guilty of indulging in unnatural practices below one of London's most beautiful bridges." There was a parallel.

Roddy had tired of communion and was zigzagging along the margin of the open ground, snuffling happily at evidence of a world beyond human perception. He had been a wonderful companion, the real instigator of twelve years of regular walking. He tried to suppress the thought that he was as sorry to say good-bye to Roddy as to Sylvia.

But now the dog was saying "come on," not "good-bye." The walk needed completion, company.

"Sorry, boy. No walkies."

He patted the dog's head. Instead of whining, his usual reaction to unreasonable procrastination, Roddy sat resignedly by the chair, looking contentedly out across the grassy slope to the distant shining sea.
Roddy's joined me. I hope he'll have the sense to go home when he sees I'm not coming. It may be cheek to ask this in the circumstances, but please don't let him miss his exercise. The paperboy might take him when he walks his mother's dog. They're both labradors.

Again his attention wandered. A large bird was soaring in wide slow spirals over the hill, its tail expanded, the broad rounded wings not moving in relation to his body. Because it was in silhouette against the bright sky, he could not see the colouring, but he knew it was a buzzard. Not a rare bird, of course, but uncommon enough on the Downs to awaken that slight flicker of excitement he had first known as a boy when no prospect made term more endurable than that of spending the weeks' freedom with binoculars and camera on the Dales of his childhood.

Roddy was lying down now, his head resting on his front paws, his eyes fixed on the horizon. It was out of character. He was a push-on dog, disinclined to waste good scent-pursuing minutes taking time out for little rests by the wayside. It was Roddy's seemingly inexhaustible demands that of late had made it increasingly difficult to exercise him. A game leg needs a break every now and then, and Roddy was for total commitment.

"All right, boy?" he said, placing his hand on the dog's haunch.

The animal sighed, got up, turned round twice, then resettled, facing him, eyes meeting his.

He tried to marshall his thoughts:

Don't forget to reset the thermostat on the boiler when it turns colder. It saves oil.

There's a lot of sludge in the tube-gauge by the tank. This may affect the reading next time it's filled. Ask the tanker driver if he'll clear it for you next time. It's only a question of easing a couple of screws on the clamp and pouring out the muck. I have cleared the gutters of leaves and there shouldn't be many more this year. In future, best get George to see to them. And he'll have to take over the pruning, I'm afraid. You'd better lend him my R.H.S. leaflet on the care of fruit trees.

His eyes were feeling heavy. Sun, sickness pill, gin ... He shook his head. He was so warm in the 
sun that he pulled the knot of his tie and undid the top button of his shirt. A great peace threatened his determination...

When he looked at his watch he realized he had slept for over an hour. The sky was still cloudless, but he felt slightly chilled, though the breeze revealed by the tops of the encircling trees did not reach him in the warm hollow. Roddy had not moved, though his eyes were closed.

"You're making a balls-up of this," he muttered.

He shivered and wrapped the free ends of the rug round him. His letter dropped on to the dog's paws, waking him.

He couldn't even finish the bloody letter, let alone ...

I've left a list of things in my desk, including a full statement of the financial position. You shouldn't have any worries on that score. The insurance won't be affected, by the way ...

Charles had said take the sickness pill an hour beforehand. It was now over an hour. He had better get on with it.

So there we are, old girl. Sorry again about any initial shock, but I think you'll feel it was for the best in the long run. It's become a damned stupid world and believe me I am less sorry to say good-bye to it than to you and Roddy. All my love, Toby.

It wasn't much of an ending, and perhaps he should have left out Roddy, but best to let it come naturally.

The dog had stood up and stretched and was now sitting on his haunches regarding him, making none of his usual attempts to purge idleness by action.

He picked up the small bottle again and unscrewed the top, tipping its contents on to the palm of his left hand. He counted each capsule slowly. Twenty exactly.

Roddy sniffed hopefully and licked his chops. The charms of confectionary had never been lost on him. His favourites, "love bombs" from the village shop, were a similar shape to the capsules, though more brightly coloured, and were also kept in a small bottle. An unsuitable passion for a doctored labrador.

"Not for you, old boy."
He took a little more gin. He would have preferred a sandwich; it was well past mid-day. Well, this was it, then.

He poured the capsules back into the bottle, then tipped two out into his palm. One swig to each pair and that would be that.

The dog whimpered, his eyes still fixed on him, but instead of rushing off in his usual heavy, hintdropping way he just sat there, staring.

"Go on," he said, "go find a pheasant."

Roddy thumped his tail on the moss-padded ground but made no further move.

"Go on," he urged, "go find something."

A squirrel was spiralling up a beech bole, claws audibly scratching the smooth bark, bright eyes alert for life's wide repertoire of perils. The labrador mildly enjoyed getting a rise out of treerats, as George called them, but this one he ignored. He lay down again, his eyes still on the man's.

Daft animal! Why did one get so damnably attached to them? He knew why, and it had everything to do with what animals were and humans are not. Sylvia had thought it absurd that a year or more ago, before he had even laid plans for his own exit, he had decided how Roddy was to be put down. Now he would not be able to supervise this. Still, Sylvia knew he wanted it done humanely, at home. If nothing else got him first, of course such as a lorry if left to find his own way back ...

He expelled breath between clenched teeth, in resigned irritation, feeling guilt; not because of the mythical lorry so much as because the parallel in their ages had come home to him. The animal was twelve, nearly thirteen. In his eighties if you went along with that seven to one idea. Older than himself.

"Bloody hell!" he said aloud. He was still holding the two capsules in his palm and they were getting sticky. He wasn't winning.

The thought of anti-climax prompted a moment of inner panic. After all that forward planning, all that heart-searching ... He shot the capsules into his mouth, helping them down with a nip of the gin.

Roddy whimpered, but not with the accompanying business that he laid on when wanting a walk.

"Damn you," he said, "bugger off home."

The dog moved nearer, butting gently at his 
hand. He guessed his momentary panic had been sensed. He patted Roddy's head, then left his hand there, and the dog closed his eyes, content.

The mid-day sun was almost too much. He lay back in the chair, the drug bottle in one hand, remembering some of the animal's proofs of intelligence and empathy. They were private memories. It was all too easy to be charged with reading too much in to an animal's behaviour. Even Sylvia, though reasonably fond of Roddy, had little patience with what she called anthropomorphizing. Her training had been in biology. God, it seemed mean leaving the poor bloody animal behind. Would Sylvia even bother to get the paper-boy to walk him? He still had so much go in him, for all his twelve years.

He fought conscience, but in the quiet beauty of his surroundings his mind worked with disturbing clarity. He argued against the self-judgment of disloyalty to this sloppy four-legged creature in whose company he had spent the happiest hours for years past. But a stronger voice was telling that a better order of play would have been to see the dog's natural life out before he took his own. A couple of years, if he made it that long, and he would have no obligation.

The sun had brought the sweat out on his forehead. The blue of the sky almost hurt his eyes. He shut them, and a few moments later his right hand slipped from the dog's warm head; his left relaxed, allowing the bottle to tilt and spill its contents on to his lap. Some of the capsules rolled off on to the brown compacted carpet of dead moss and leaf-mould. They glinted invitingly there in the warm sun, not unlike harmless "love bombs." In the impenetrable tangle of a bramble bush on the forest's edge a cock pheasant churred and chukkered to its mate, at peace with a world visibly and audibly at peace.

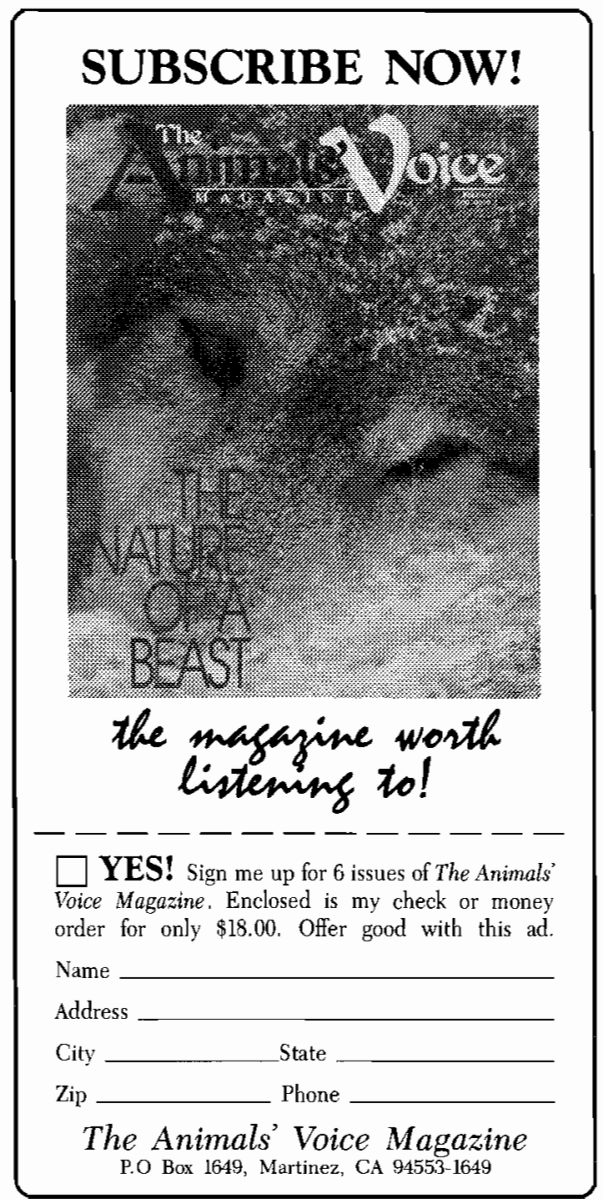

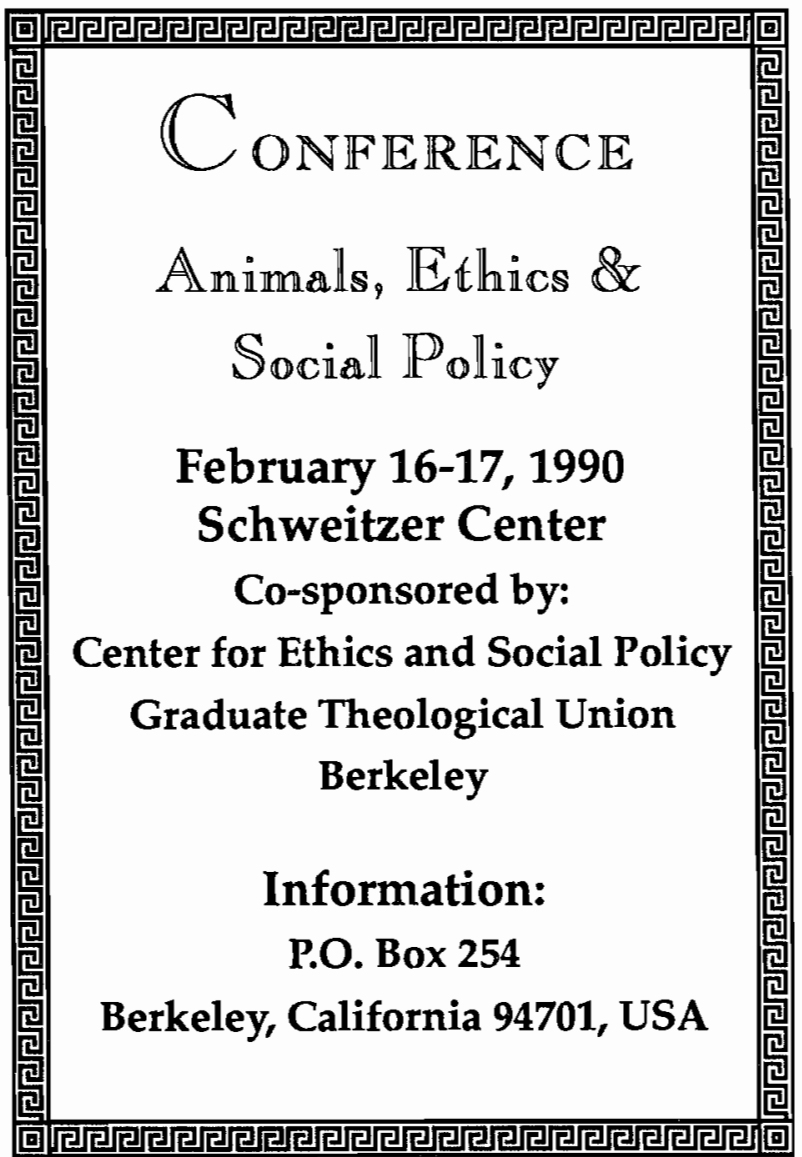

